\title{
EFFECTS OF Si ADDITION ON THE HIGH TEMPERATURE STRENGTH AND OXIDATION BEHAVIOR OF $\gamma^{\prime}$-BEARING Co-BASED SUPERALLOYS
}

\author{
An-Chou Yeh, I-Ting Ho, Sheng-Chi Wang, Chia-Fu Cheng \\ Department of Materials Science and Engineering, National Tsing Hua University, Hsinchu, 30013, Taiwan R.O.C. \\ Keywords: Co-based superalloys, silicon addition, high temperature hardness, high temperature oxidation
}

\begin{abstract}
This article aims to present the effect of $\mathrm{Si}$ addition on the microstructure, elemental partitioning, high temperature hardness, and oxidation behavior for $\gamma^{\prime}$-bearing Co-based superalloy. The fraction of $\gamma^{\prime}$ phase can be increased with the addition of $\mathrm{Si}$, rendering an improvement on hardness at elevated temperatures. Furthermore, Si partitions preferentially toward $\gamma^{\prime}$ phase and affects partitioning behavior of $\mathrm{W}$. Isothermal oxidation tests conducted at $900^{\circ} \mathrm{C}, 1000^{\circ} \mathrm{C}$, and $1150^{\circ} \mathrm{C}$ have indicated that Si additions can improve oxidation resistance. Furthermore, the content of $\mathrm{W}$ can have a profound impact on the oxidation behavior; low content of $\mathrm{W}$ can reder the formation of protective $\mathrm{Al}_{2} \mathrm{O}_{3}$ at temperatures at and above $1000^{\circ} \mathrm{C}$, while high $\mathrm{W}$ content can slow down oxidation at $900{ }^{\circ} \mathrm{C}$.
\end{abstract}

\section{Introduction}

The thermal efficiency of gas turbine engines depends on the temperature capability of materials used in the turbine section [1]. Most of the turbine section components are made of Ni-based superalloys due to their ability to precipitate high temperature stable $\gamma^{\prime}$ or $\gamma^{\prime \prime}$ [2, 3]. In 2006, a new type of Co-based superalloy containing $\gamma^{\prime}$ phase with a chemical formula of $\mathrm{Co}_{3}(\mathrm{Al}, \mathrm{W})$ was reported [4]; it contains $\mathrm{L}_{2} \gamma^{\prime}$ microstructure and offers potential to replace conventional Ni-based superalloys. Many studies have focused on alloy design to improve mechanical properties [4-8] and to raise $\gamma^{\prime}$ solvus temperature [7,9-11]. With respect of the surface stability, studies have shown that $\mathrm{Cr}$ addition could provide protection by forming $\mathrm{Cr}_{2} \mathrm{O}_{3}$ at $800{ }^{\circ} \mathrm{C}$, however, it also destabilizes the cuboidal morphology of $\gamma^{\prime}$ and lead to degradation in mechanical properties [12]. Since $\mathrm{Cr}_{2} \mathrm{O}_{3}$ becomes less protective at temperatures above $1000{ }^{\circ} \mathrm{C}[2,13]$. The formation of $\mathrm{Al}_{2} \mathrm{O}_{3}$ is needed for higher temperature applications [14]. Previous studies have indicated that $\mathrm{Si}$ additions can promote the formation of $\mathrm{Al}_{2} \mathrm{O}_{3}$ and improve the adhesion between $\mathrm{Al}_{2} \mathrm{O}_{3}$ and the substrate of Nibased superalloys [15-18]. Similar concepts have been exploited by Klein et al. [5] on some other Ni-bearing Co-based superalloys; although oxidation resistance can be improved, the formation of $\mathrm{Al}_{2} \mathrm{O}_{3}$ does not seem to be dense and continuous in previous studies.

Although it has been reported that $\mathrm{Si}$ additions can improve the oxidation resistance of Co-based superalloys by promoting formation of $\mathrm{Al}_{2} \mathrm{O}_{3}$, very little is known about its effect on elemental partitioning and lattice misfit that can have a profound impact the mechanical properties at elevated temperatures. Since Si-bearing Co-based superalloys appear to be a promising direction for future alloy design, the purpose of this research is to uncover the effects of $\mathrm{Si}$ on elemental partitioning, microstructure and hardness, as well as oxidation behavior.

\section{Experimental procedure}

Compositions of interests are shown in Table 1; alloys are based on the Co-Al-W-Ni-Si alloy systems containing $0-2.0$ at $\% \mathrm{Si}$; FC2.0 and CS- 4 both contain 2.0 at $\% \mathrm{Si}$, and the $\mathrm{W}$ content is reduced by half to $5.0 \mathrm{at} \%$ in CS- 4 . A total of $40 \mathrm{~g}$ of raw materials were prepared by vacuum arc melting for each alloy; ingots were melted four times to ensure uniform compositions. $\gamma^{\prime}$ solvus was analyzed by differential scanning calorimetry (NETZSCH DSC 404) at a heating rate of $10{ }^{\circ} \mathrm{C} \cdot \mathrm{min}^{-1}$ and then cooled at a cooling rate of 20 ${ }^{\circ} \mathrm{C} . \mathrm{min}^{-1}$. As-cast ingots were sealed in quartz tubes with vacuum atmosphere, and then were subjected to solution heat treatment at $1250^{\circ} \mathrm{C}$ for $20 \mathrm{~h}$, followed by ageing below the $\gamma^{\prime}$ solvus at $900{ }^{\circ} \mathrm{C}$ for $168 \mathrm{~h}$. Samples were ground, polished and etched with $100 \mathrm{ml}$ distilled water, $100 \mathrm{ml} \mathrm{HCl}$ and $0.5 \mathrm{~g} \mathrm{~K}_{2} \mathrm{~S}_{2} \mathrm{O}_{5}$ for $40 \mathrm{~s}$. Microstructures were observed by scanning electron microscope (Hitachi SU8010) at a voltage of $15 \mathrm{kV}$. The compositions of phases were determined by the electron probe microanalyzer (EPMA, JEOL JXA-8500) coupled with wavelength dispersive spectroscopy (WDS) operated at a voltage of $12 \mathrm{kV} . \gamma^{\prime}$ particles were coarsened for reliable composition measurements, and details of the experimental procedure is described in previous work [15]. Phase identification and lattice misfits were determined by X-ray diffractometer (XRD, Shimadzu XRD-6000) under radiation conditions of $30 \mathrm{kV}, 20 \mathrm{~mA}, \mathrm{Cu}$ target (K $\alpha$ radiation, $1.54056 \AA)$ with scanning speed of $2^{\circ} \cdot \mathrm{min}^{-1}$. The lattice parameters of $\gamma$ and $\gamma^{\prime}$ phases were determined by deconvoluting (200) diffraction peak into $\gamma$ and $\gamma^{\prime}$ sub-peaks to calculate the lattice misfit $\delta=2\left(a_{\gamma^{\prime}}\right.$ $\left.a_{\gamma}\right) /\left(a_{\gamma^{\prime}}+a_{\gamma}\right)$, where $a_{\gamma^{\prime}}$ and $a_{\gamma}$ are lattice parameters of $\gamma^{\prime}$ and $\gamma$, respectively. Hardness of samples were measured by a high temperature Vickers hardness tester (Model AVK-HF, Akashi) equipped with a vacuum chamber and a heating unit. All specimens were tested from room temperature up to $1027^{\circ} \mathrm{C}$ under the argon. A load of $49 \mathrm{~N}$ and a dwell time of $15 \mathrm{~s}$ was used. The heating rate of the sample was $10{ }^{\circ} \mathrm{C} \cdot \mathrm{min}^{-1}$ and 10 indentations were made to get an average value. The indentor material was diamond, and indentation positions were all within individual grains. All specimen surfaces were ground by 1200 -grit sand paper and then ultrasonically cleaned in ethanol and dried before experiments. Isothermal oxidation tests were carried out at $900{ }^{\circ} \mathrm{C}, 1000{ }^{\circ} \mathrm{C}$ and $1150{ }^{\circ} \mathrm{C}$ for $5,48,96,146 \mathrm{~h}$ in a box furnace. At each time interval, samples were removed from the furnace and the weight of oxidized samples were measured by electronic weighting balance with sensitivity down to $10^{-5} \mathrm{~g}$, and weight gains were determined by subtracting the weight of the original sample from the weight of the oxidized sample.

\section{Results and Discussion}

Figure 1 shows the as-cast, solution heat treated and aged microstructures of FC-0.0, FC-1.0, FC-2.0 and CS-4 alloys. For Si 
contents higher than 2.0 at $\%, \mu$ phase has been identified and cannot be re-solutioned after heat-treatment [19]. The as-cast microstructure contains dendrites, and residual segregation can be eliminated after solution heat treatment. Ordered $\gamma^{\prime}$ precipitates are present in FC alloys and CS-4 after solution and ageing heat treatment, and they appear to be homogeneously distributed in $\gamma$ matrix.

Table I. Nominal compositions (at $\%$ )

\begin{tabular}{|c|c|c|c|c|c|}
\hline Element & Co & Ni & Si & Al & W \\
\hline FC-0.0 & Bal. & 30 & 0.0 & 10 & 10 \\
\hline FC-0.5 & Bal. & 30 & 0.5 & 10 & 10 \\
\hline FC-1.0 & Bal. & 30 & 1.0 & 10 & 10 \\
\hline FC-1.5 & Bal. & 30 & 1.5 & 10 & 10 \\
\hline FC-2.0 & Bal. & 30 & 2.0 & 10 & 10 \\
\hline CS-4 & Bal. & 30 & 2.0 & 10 & 5.0 \\
\hline
\end{tabular}

To understand the effect of $\mathrm{Si}$ on microstructures, the elemental partitioning coefficients, $\mathrm{K}$, are obtained. $\mathrm{K}=\mathrm{C}_{\gamma^{\prime}} / \mathrm{C}_{\gamma}$, where $\mathrm{C} \gamma^{\prime}$ is the concentration of element in $\gamma^{\prime}$, and $\mathrm{C} \gamma$ is the concentration of element in $\gamma$. Element with $\mathrm{K}>1$ corresponds to partitioning toward $\gamma^{\prime}$ phase, whereas $\mathrm{K}<1$ represents partitioning to $\gamma$ phase. Particlecoarsening method was employed, Figure 2, and results are summarized in Table 2 and Figure 3 ; it indicates that $\mathrm{Ni}, \mathrm{Al}, \mathrm{W}$ and Si partition preferentially to $\gamma^{\prime}$ phase; Co partitions preferentially to $\gamma$ phase. Since Si is a $\gamma^{\prime}$ forming element, is it likely that Si prefers $\mathrm{Al}$ sites than Co sites in the $\mathrm{L} 12$. The partition coefficient of $\mathrm{W}$ is decreased and that of $\mathrm{Al}$ is increased with increasing Si content, so higher $\mathrm{Al}$ content and lower $\mathrm{W}$ content in $\gamma^{\prime}$ can result higher solvus temperature, possibly due to less disordering of the $\mathrm{L}_{2}$. The addition of Si can modify the size and volume fraction of $\gamma^{\prime}$ significantly, Table II. Comparing to FC-0.0, with 2.0 at $\% \mathrm{Si}$ addition, the $\gamma^{\prime}$ volume fraction of $\gamma^{\prime}$ have been increased by $11 \%$; Si seems to be a strong $\gamma^{\prime}$ forming element in the Co-Al-W-Ni system. And the reduction in $\mathrm{W}$ has decreased the volume fraction of $\gamma^{\prime}$ in CS-4 significantly from $82.6 \%$ to $39.8 \%$.

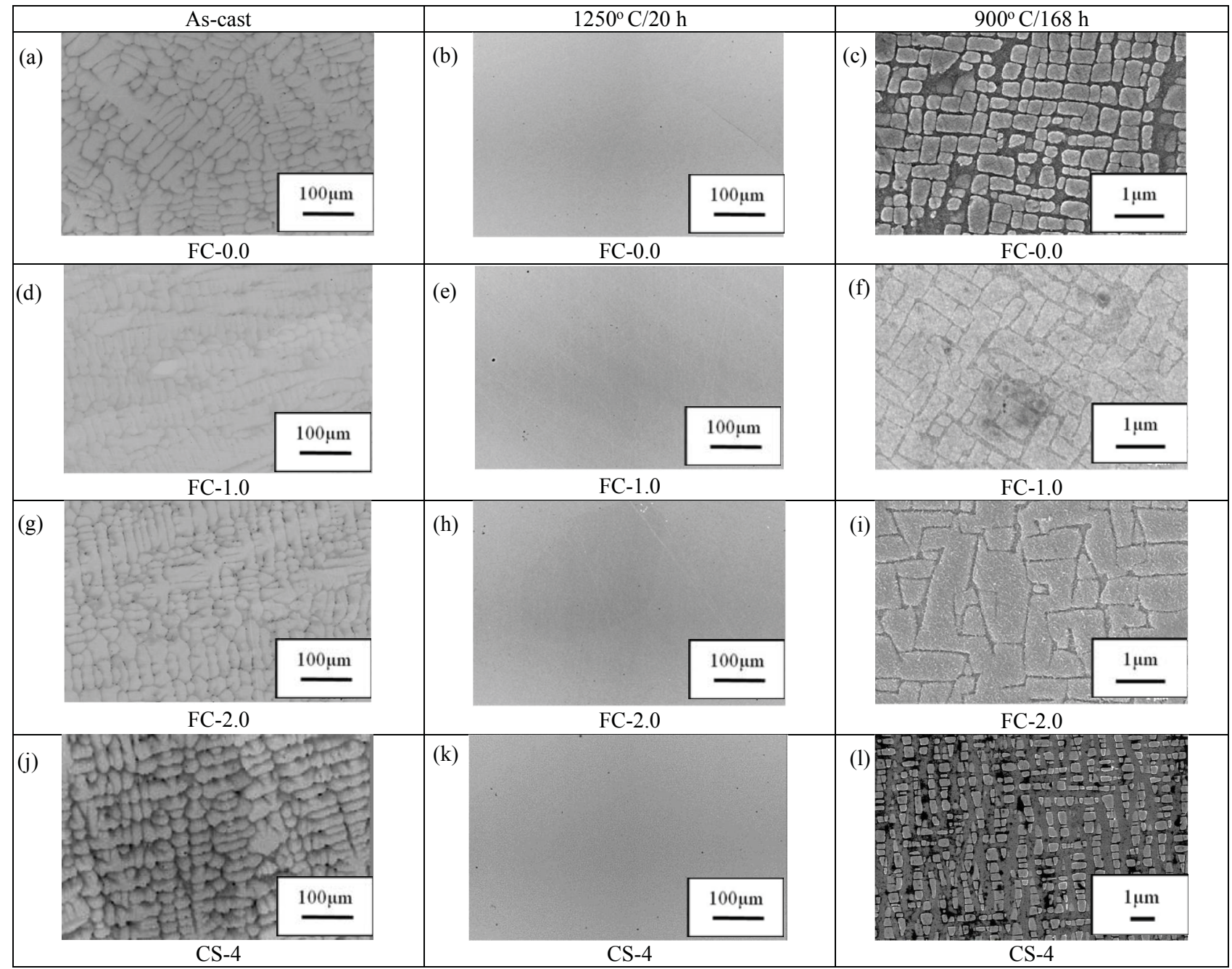

Figure 1. As-cast, solution-heat-treated condition (SHT), and SHT+ageing condition for FC-0.0, FC-1.0, FC-2.0, and CS-4. 


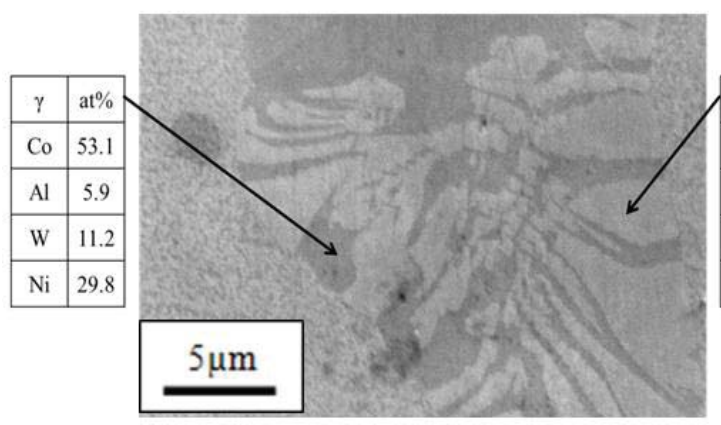

(a)

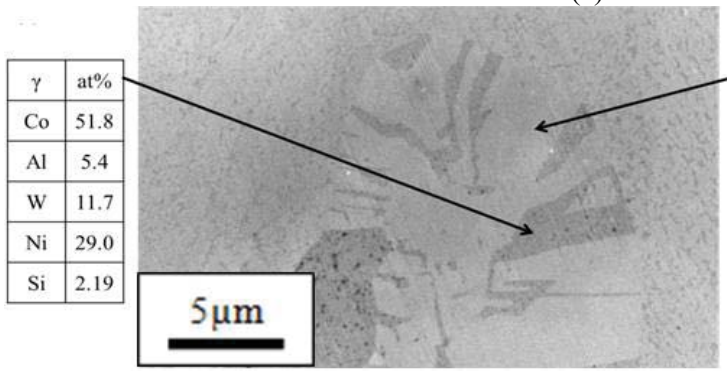

(c)

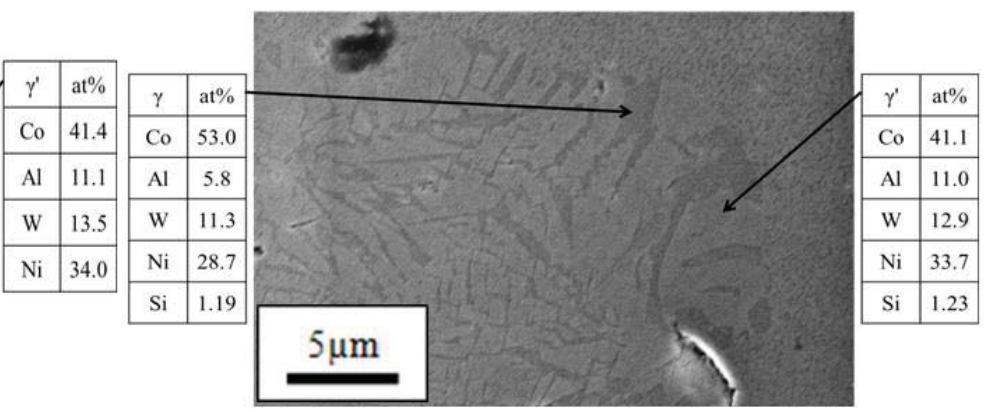

(b)

Fig 2. Microstructure of cellular $\gamma / \gamma^{\prime}$ with composition analyzed by EPMA,

$\begin{array}{llll}\text { (a) FC-0.0 } & \text { (b) FC-1.0 } & \text { (c) FC-2.0 } & \text { (d) } \text { CS-4 }\end{array}$

Table II. Elemental partitioning coefficients, $\gamma^{\prime}$ vol\% and lattice misfits

\begin{tabular}{|c|c|c|c|c|c|c|c|}
\hline & $\mathrm{Co}$ & $\mathrm{Al}$ & $\mathrm{W}$ & $\mathrm{Ni}$ & $\mathrm{Si}$ & $\gamma^{\prime}$ vol.\% & $\delta(\%)$ \\
\hline FC-0.0 & 0.78 & 1.88 & 1.2 & 1.14 & & 74.3 & 0.272 \\
\hline FC-1.0 & 0.77 & 1.89 & 1.14 & 1.17 & 1.03 & 76.8 & 0.263 \\
\hline FC-2.0 & 0.77 & 1.96 & 1.12 & 1.17 & 1.04 & 82.6 & 0.246 \\
\hline CS-4 & 0.8 & 1.44 & 1.78 & 1.17 & 1.001 & 39.8 & - \\
\hline
\end{tabular}

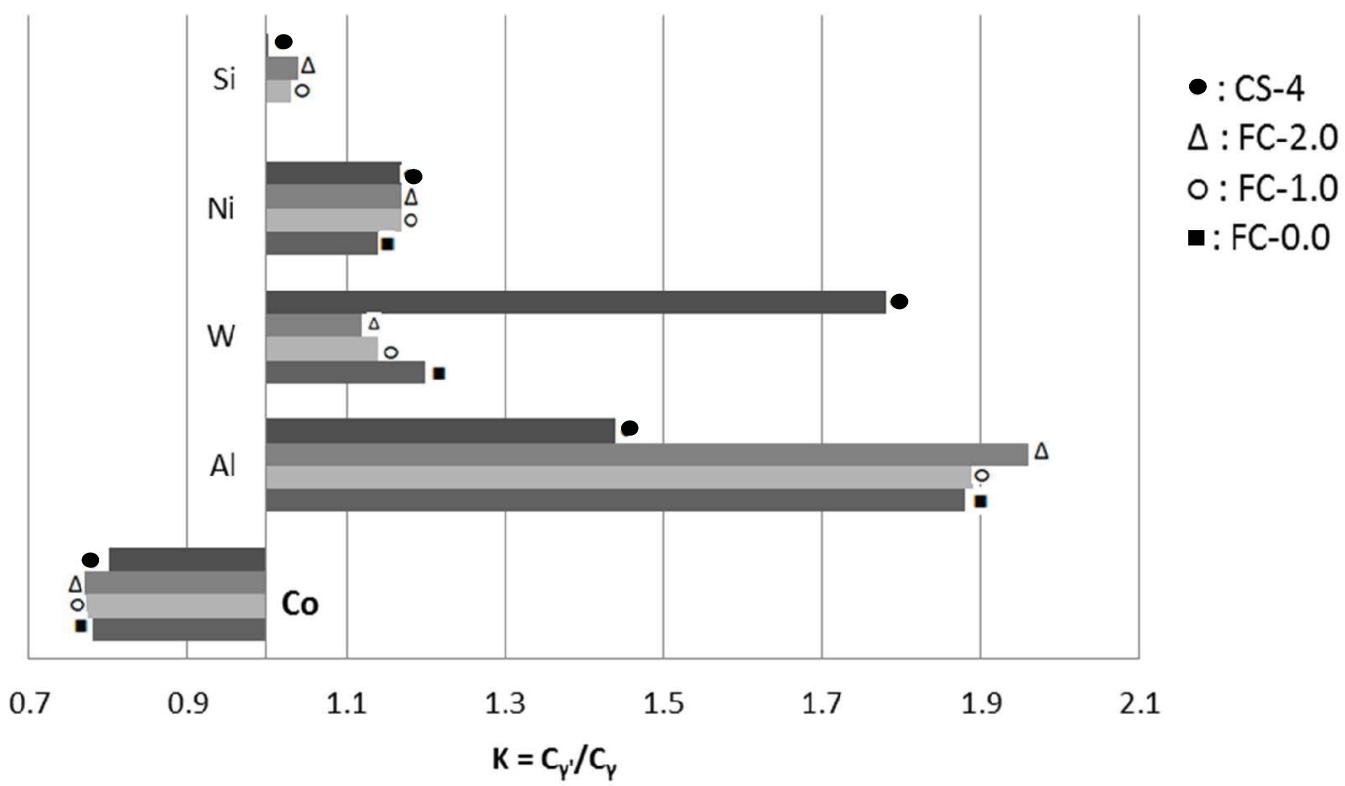

Figure 3. Partitioning behaviors of elements in FC-0.0, FC-1.0, FC-2.0 and CS-4. 
The lattice misfits between $\gamma$ and $\gamma^{\prime}$ have been decreased from 0.272 $\%$ to $0.246 \%$ from FC-0.0 to FC-2.0, Table II. And, it is possible that increase in $\gamma^{\prime}$ volume fraction is a result of both increasing $\mathrm{Si}$ content and higher $\mathrm{K}$ value of $\mathrm{Al}$. The partition behavior of $\mathrm{W}$ may also explain the decrease in lattice misfit from FC-0.0 to FC-2.0, since there are more $\mathrm{W}$ content in the $\gamma$ phase with higher content of $\mathrm{Si}$, the lattice parameter of $\gamma$ can expand more to match that of $\gamma^{\prime}$. For advanced Ni-based superalloys, negative lattice misfit is preferred for the formation of N-raft microstructure, which can hinder dislocation climb effectively.

The effect of $\mathrm{Si}$ on the partitioning behavior of $\mathrm{W}$ indicates its influence on lattice misfit and role to in-directly alter the mechanical properties of Co-based superalloys. Figure 4 shows the hardness results. Among three FC alloys, FC-0.0 has the highest hardness at room temperature, whereas alloys with higher $\mathrm{Si}$ contents are softer, and the decrease of $\mathrm{K}$ value of $\mathrm{W}$ with higher $\mathrm{Si}$ content may be the underlying cause. In other words, as the $\mathrm{Si}$ content increases, the concentration of $\mathrm{W}$ in $\gamma^{\prime}$ would be reduced. As a result, FC-2.0 can be softer than FC- 0.0 due to its $\gamma^{\prime}$ containing lower amounts of $\mathrm{W}$, which is known to provide solid solution strengthening and may increase the anti-phase-boundary energy. However, FC-2.0 is harder than FC-0.0 and FC-1.0 at higher temperature $\left(1027^{\circ} \mathrm{C}\right)$ owing to higher $\gamma^{\prime}$ fraction. For comparisons, data of IN718 have been included (subjected to standard $720^{\circ} \mathrm{C} 8 \mathrm{~h}$ $+620^{\circ} \mathrm{C} 8 \mathrm{~h}$ ageing). $\mathrm{FC}$ alloys exhibit higher hardness throughout all temperatures, especially at elevated temperatures owing to high temperature stable $\gamma^{\prime}$ phase. IN718 is strengthened by $\mathrm{Ni}_{3} \mathrm{Nb} \gamma^{\prime \prime}$ $\left(\mathrm{DO}_{22}\right)$, which is stronger than $\mathrm{L} 1_{2} \gamma^{\prime}$, however $\gamma^{\prime \prime}$ is only stable until $650{ }^{\circ} \mathrm{C}$, beyond it, $\gamma^{\prime \prime}$ would transform to $\delta$ phase leading to degradation in mechanical property. The reduction in $\mathrm{W}$ clearly reduces the strength of CS-4 significantly due to lower volume fraction of $\gamma^{\prime}$. The addition of $2.0 \mathrm{at} \% \mathrm{Si}$ can increase the volume

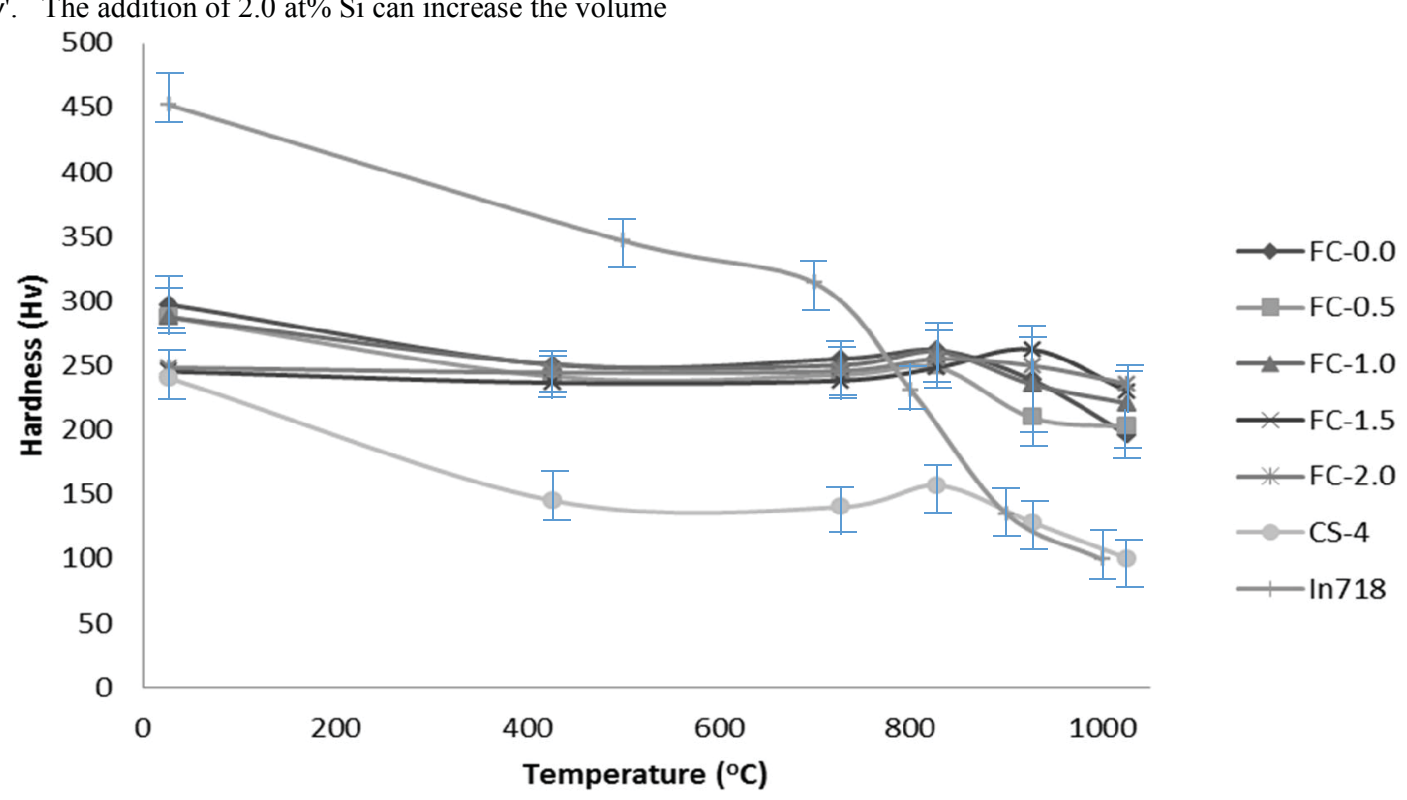

fraction and solvus temperature of $\gamma^{\prime}$, so Si addition offers potential to increase strength of advanced Co-base superalloys at elevated temperatures. The effect of Si addition on elemental partitioning behavior such as $\mathrm{W}$ may be utilized to design more negative lattice misfit alloys in the future.

The size and volume fractions of $\gamma^{\prime}$ for FC-2.0 and CS-4 are 800 $\mathrm{nm}$ and $300 \mathrm{~nm}, 80 \%$ and $30 \%$, respectively, and the only compositional difference between CS-4 and FC-2.0 is the reduced W content. Results of isothermal oxidation tests conducted at 900 ${ }^{\circ} \mathrm{C}, 1000^{\circ} \mathrm{C}$ and $1150^{\circ} \mathrm{C}$ for all alloys are illustrated in Figure 5(a), 5 (b), and 5(c), respectively. At $900^{\circ} \mathrm{C}$, oxidation weight gains for FC alloys decrease with increasing Si content. However, the effect of $\mathrm{Si}$ is only observed when $\mathrm{Si}$ content is increased from zero to 0.5 at $\%$, and from 0.5 at $\%$ to 1.0 at $\%$. Although both CS-4 with FC-2.0 contain 2.0 at $\% \mathrm{Si}$, it appears that FC-2.0 exhibits better resistance against oxidation at $900^{\circ} \mathrm{C}$ due to higher $\mathrm{W}$ content. Interestingly, CS-4 alloy has outperformed those of FC alloys at $1000^{\circ} \mathrm{C}$, and FC alloys exhibit the same trend of oxidation behavior as that shown at $900{ }^{\circ} \mathrm{C}$. The oxidation resistance of CS-4 is significantly better than those of $\mathrm{FC}$ alloys at $1150{ }^{\circ} \mathrm{C}$, furthermore, more pronounced effect of Si addition can be seen for FC alloys, as the oxidation resistance does increase with more Si content. Since this oxidation weight gain behavior appears to follow the parabolic-rate law equation [20-22] which is defined by Pilling and Bedworth [23]:

$$
\left(\frac{\Delta m}{A}\right)^{2}=K_{p} t+C
$$

where $\Delta m$ is weight gain after a certain time t, $A$ is the surface area of metal, $K_{p}$ is parabolic rate constant in the unit of $g^{2} \mathrm{~cm}^{-4} \mathrm{sec}^{-1}$, and $C$ is a constant. The $K_{p}$ values and weight gain after $146 \mathrm{~h}$ are determined and listed in Table IV.

Figure 4. Hardness vs. temperature for FC series alloys, CS-4, and In718 
Higher $K_{p}$ value implies faster oxidation rate, thus lower resistance against oxidation. At $1150{ }^{\circ} \mathrm{C}, \mathrm{CS}-4$ possesses a $K_{p}$ value, which is several orders of magnitude lower than those of FC alloys; after $146 \mathrm{~h}$, its oxidation weight gain is $6.79 \mathrm{mg} . \mathrm{cm}^{-2}$ comparing to 110.1 mg.cm ${ }^{-2}$ of FC-2.0. After $146 \mathrm{~h}$ at $1000^{\circ} \mathrm{C}$, oxidation weight gain of CS-4 and FC-2.0 are $11.7 \mathrm{mg} \cdot \mathrm{cm}^{-2}$ and $27.5 \mathrm{mg} . \mathrm{cm}^{-2}$, respectively. At $900{ }^{\circ} \mathrm{C}$, the oxidation weight gain for CS-4 and FC2.0 are $13.3 \mathrm{mg} . \mathrm{cm}^{-2}$ and $8.0 \mathrm{mg} . \mathrm{cm}^{-2}$ after $146 \mathrm{~h}$, respectively. A clear trend has emerged from Figure 5 and Table IV, the effect of $\mathrm{Si}$ on oxidation behavior appears to be more pronounced at higher temperatures, and reduced W content coupled with Si addition (CS4 vs FC-2.0) seems to yield much better resistance against oxidation at higher temperature, Figure 5(c). While higher W content can be beneficial for lower temperature condition, Figure 5 (a). Cross-sectional micrographs of oxidized FC-0.0, FC-1.0, FC2.0 and CS-4 alloys at $1150^{\circ} \mathrm{C}$ for $146 \mathrm{~h}$ are shown in Figure 6, and the XRD analysis for oxidized CS-4 is shown in Figure 7. The extent of oxidation at $1150{ }^{\circ} \mathrm{C}$ can be seen from the thickness of external cobalt oxide, after $146 \mathrm{~h}$, and it is clear that higher $\mathrm{Si}$ content can provide better oxidation resistance for FC alloys; FC2.0 contains a total thickness of $800 \mu \mathrm{m}$ oxidized layer consisting of external $\mathrm{CoO}$, middle layer of $\mathrm{CoAl}_{2} \mathrm{O}_{4}$, internal $\mathrm{CoWO}_{4}$ and discontinuous $\mathrm{Al}_{2} \mathrm{O}_{3}$. By contrast, the oxide thickness of CS-4 is less than $20 \mu \mathrm{m}$, and it possesses a dense and continuous $\mathrm{Al}_{2} \mathrm{O}_{3}$, which is shown by the EDS analysis and can be detected by XRD; no Si segregation can be observed. The oxide constituents for FC alloys and CS-4 at $1000^{\circ} \mathrm{C}$ and $900^{\circ} \mathrm{C}$ are the same as that of 1150 ${ }^{\circ} \mathrm{C}$. Figure 6 shows that at $1000^{\circ} \mathrm{C}, \mathrm{FC}$ alloys contain external $\mathrm{CoO}$, middle layer of $\mathrm{CoAl}_{2} \mathrm{O}_{4}$, internal $\mathrm{CoWO}_{4}$ and discontinuous $\mathrm{Al}_{2} \mathrm{O}_{3}$, while CS-4 possesses continuous $\mathrm{Al}_{2} \mathrm{O}_{3}$ after $146 \mathrm{~h}$ and the overall oxide thickness is thinner than those of FC alloys.

The cross sectional micrographs at $900{ }^{\circ} \mathrm{C}$ reveal the same type of oxides present in FC alloys after $146 \mathrm{~h}$. The oxidized layer of CS4 has a continuous $\mathrm{Al}_{2} \mathrm{O}_{3}$, however, its overall thickness of the oxidized layer is similar to that of FC alloys (Figure 6(g), 6(h)). Initial stage of oxidation for CS- 4 at $900{ }^{\circ} \mathrm{C}$ and $1000{ }^{\circ} \mathrm{C}$ are shown in Figure 6; no protective $\mathrm{Al}_{2} \mathrm{O}_{3}$ could be observed after $5 \mathrm{~h}$ at 900 ${ }^{\circ} \mathrm{C}$, (Figure 6(c), 6(d)). High temperature alloys usually rely on the formation of $\mathrm{Al}_{2} \mathrm{O}_{3}$ and $\mathrm{Cr}_{2} \mathrm{O}_{3}$ for surface protection at elevated temperatures [2]. Protective $\mathrm{Cr}_{2} \mathrm{O}_{3}$ for alloys is common for application temperatures below $1000^{\circ} \mathrm{C}$, however, for the materials that are expected to be used at higher temperatures, formation of $\mathrm{Al}_{2} \mathrm{O}_{3}$ would be necessary due to its greater thermal stability and low oxygen permeability. In the previously reported studies [12, 14], the Co-Cr-Al-W systems could form internal continuous $\mathrm{Cr}_{2} \mathrm{O}_{3}$ or $\mathrm{Al}_{2} \mathrm{O}_{3}$ layers, however its $\mathrm{Co}_{3}(\mathrm{Al}, \mathrm{W})$ is not stable, unless $\mathrm{Ni}$ is added in the system in significant quantities, hence the Ni-bearing Co-based systems have been introduced. However, so far there has been no reported Ni-bearing Co-based alloy systems that actually grow continuous $\mathrm{Al}_{2} \mathrm{O}_{3}$ at temperatures above $1000^{\circ} \mathrm{C}[12,14]$. To the best of our knowledge, the CS-4 is the first alloy to show continuous $\mathrm{Al}_{2} \mathrm{O}_{3}$ formation in Ni-bearing Co-based alloys (Co-Al$\mathrm{W}-\mathrm{Ni}-\mathrm{Si}$ system). Since $\mathrm{Si}$ additions can promote $\mathrm{Al}_{2} \mathrm{O}_{3}$ formation in Ni-based superalloys, it is likely that $\mathrm{Si}$ addition can also enhance the $\mathrm{Al}$ activity in Co-based superalloys [15-18], promoting more rapid formation of $\mathrm{Al}_{2} \mathrm{O}_{3}$ to decrease the rate of oxidation, and this effect appears to be more pronounced with increasing temperature from $900^{\circ} \mathrm{C}$ to $1150^{\circ} \mathrm{C}$ for $\mathrm{FC}$ alloys, Figure 5 .

Table III. Thermal properties of FC series alloys and CS-4 [24]

\begin{tabular}{|c|c|c|c|c|c|}
\hline${ }^{\circ} \mathrm{C}$ & FC-0.0 & FC-0.5 & FC-1.5 & FC-2.0 & 1387 \\
\hline Solidus & 1443 & 1430 & 1400 & 1113 & 1363 \\
\hline$\gamma^{\prime}$ Solvus & 1057 & 1075 & 1104 & 279 & 368 \\
\hline HTW & 386 & 355 & 296 & 368 \\
\hline
\end{tabular}

Table IV. Oxidation rate constant and weight gain after $146 \mathrm{~h}$ of investigated alloys [24]

\begin{tabular}{ccccccc}
\hline & \multicolumn{3}{c}{$900^{\circ} \mathrm{C}$} & \multicolumn{3}{c}{$1000^{\circ} \mathrm{C}$} \\
\cline { 2 - 7 } Alloy & $\begin{array}{c}\text { Weight } \\
\left(\mathrm{k}^{2} \mathrm{~cm}^{-4} \mathrm{sec}^{-1}\right)\end{array}$ & $\begin{array}{c}\text { Wain after } \\
146 \mathrm{~h} \\
\left(\mathrm{mg} / \mathrm{cm}^{2}\right)\end{array}$ & $\begin{array}{c}\mathrm{k}_{\mathrm{p}} \\
\left(\mathrm{g}^{2} \mathrm{~cm}^{-4} \mathrm{sec}^{-1}\right)\end{array}$ & $\begin{array}{c}\text { Weight gain after } 146 \\
\mathrm{~h} \\
\left(\mathrm{mg} / \mathrm{cm}^{2}\right)\end{array}$ & $\begin{array}{c}\mathrm{k}_{\mathrm{p}} \\
\left(\mathrm{g}^{2} \mathrm{~cm}^{-4} \mathrm{sec}^{-1}\right)\end{array}$ & $\begin{array}{c}\text { Weight gain after 146 h } \\
\left(\mathrm{mg} / \mathrm{cm}^{2}\right)\end{array}$ \\
\hline FC-0.0 & $5.42 \times 10^{-9}$ & 21.7 & $3.02 \times 10^{-8}$ & 51.8 & $5.64 \times 10^{-8}$ & 171.6 \\
FC-0.5 & $2.36 \times 10^{-9}$ & 14.1 & $1.39 \times 10^{-8}$ & 38.7 & $5.23 \times 10^{-8}$ & 165.2 \\
FC-1.0 & $8.43 \times 10^{-10}$ & 7.8 & $5.69 \times 10^{-9}$ & 23.6 & $2.99 \times 10^{-8}$ & 125.0 \\
FC-1.5 & $7.23 \times 10^{-10}$ & 7.6 & $2.67 \times 10^{-9}$ & 24.9 & $2.81 \times 10^{-8}$ & 121.4 \\
FC-2.0 & $7.89 \times 10^{-10}$ & 8.0 & $6.48 \times 10^{-9}$ & 27.5 & $2.30 \times 10^{-8}$ & 110.1 \\
CS-4 & $2.1 \times 10^{-9}$ & 13.3 & $2.56 \times 10^{-10}$ & 11.7 & $9.16 \times 10^{-11}$ & 6.79 \\
\hline
\end{tabular}


(a)

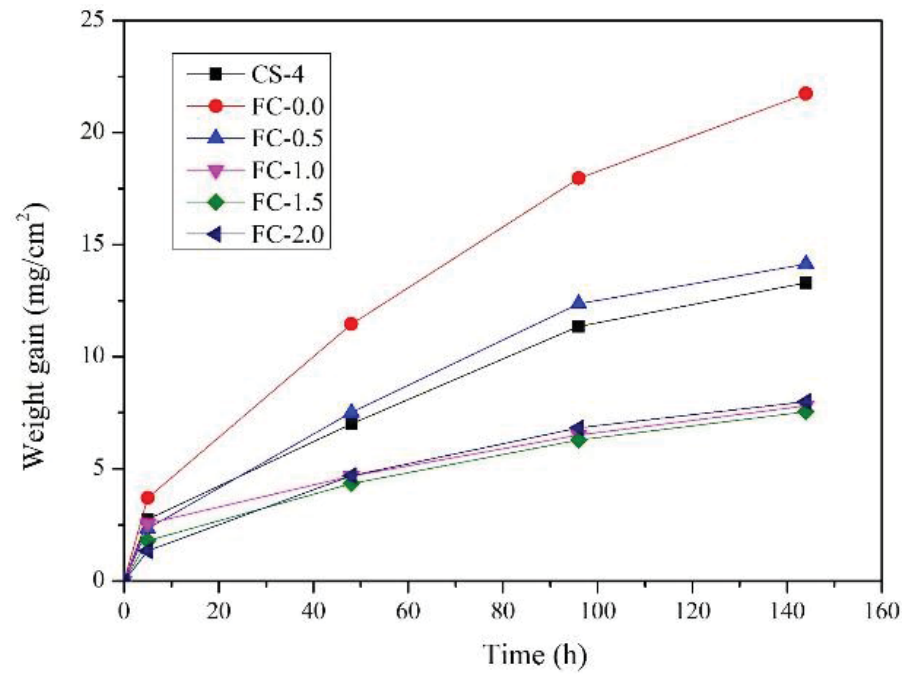

(b)

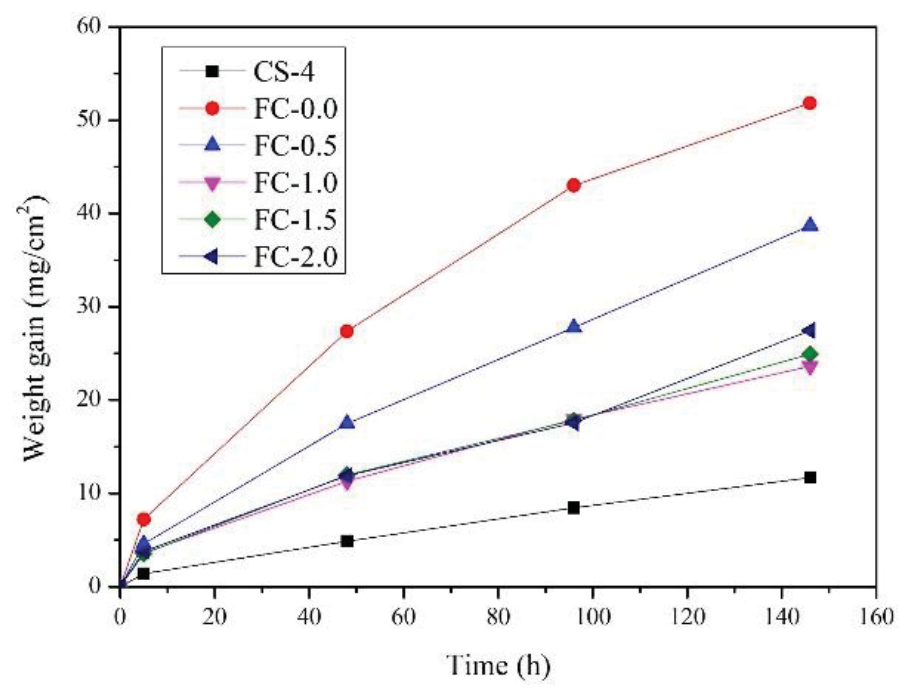

(c)

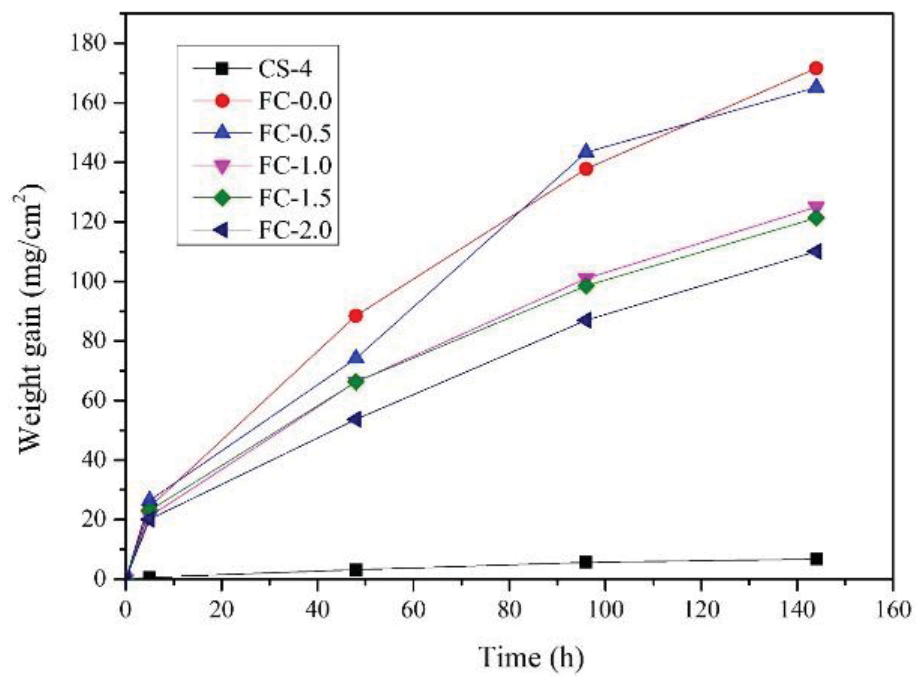

Figure 5. Weight gain of alloys after (a) $900^{\circ} \mathrm{C}$, (b) $1000^{\circ} \mathrm{C}$, (c) $1150^{\circ} \mathrm{C}$ isothermal oxidation test [24]. 


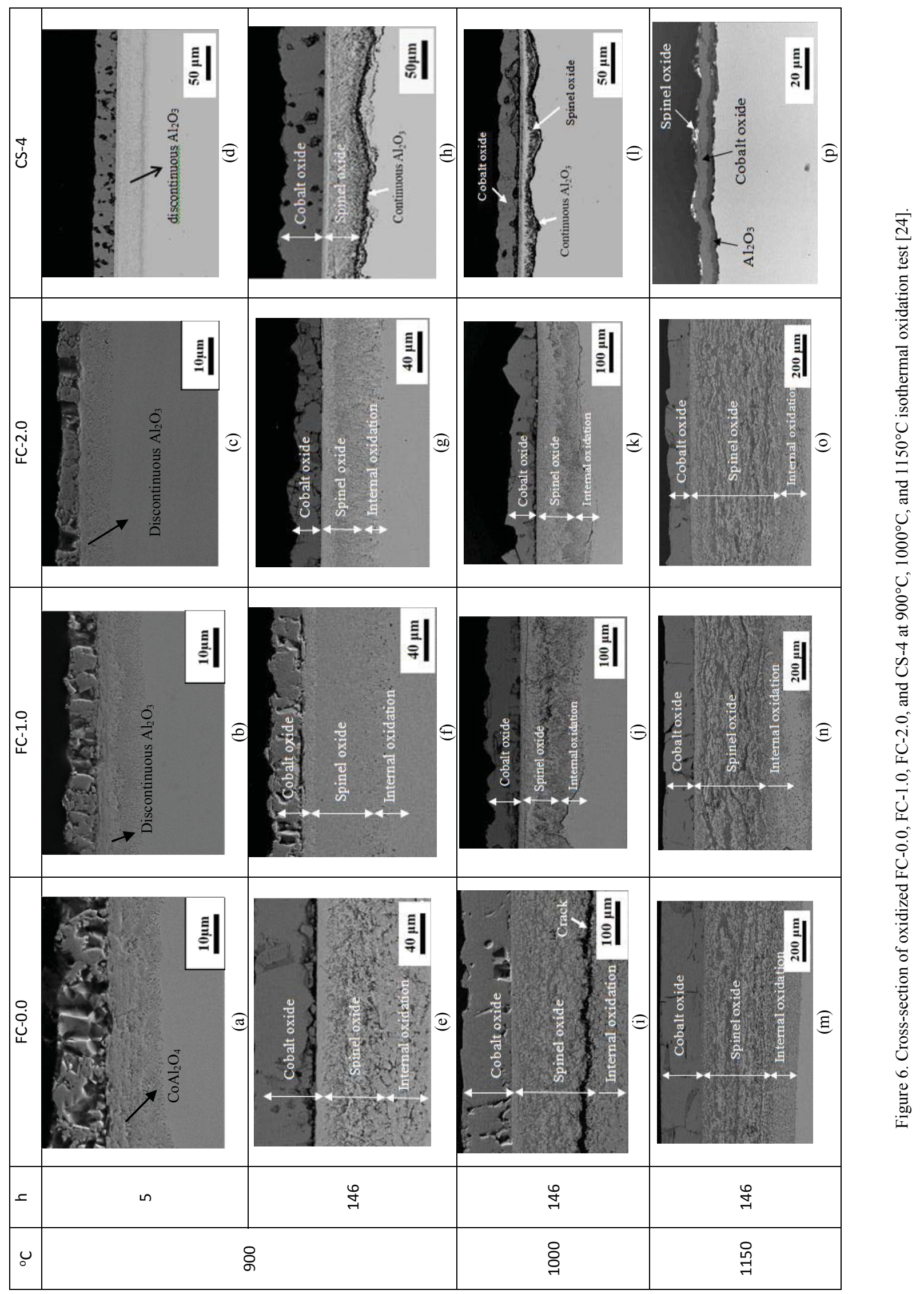




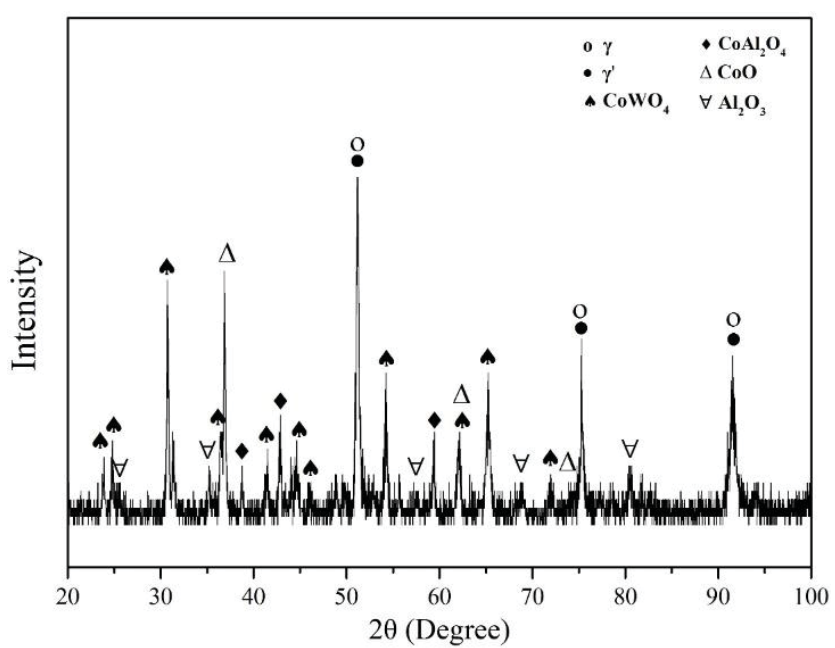

Figure 7. XRD analysis of CS-4 after oxidation at $1150{ }^{\circ} \mathrm{C}$ for $146 \mathrm{~h}[24]$.

However, none of the $\mathrm{FC}$ alloys formed continuous $\mathrm{Al}_{2} \mathrm{O}_{3}$, Figure 6. With a reduction in $\mathrm{W}$ content, it is clear that CS-4 has the ability to form continuous $\mathrm{Al}_{2} \mathrm{O}_{3}$ at each temperature. The continuous $\mathrm{Al}_{2} \mathrm{O}_{3}$ layer did not form during the early stages of oxidation at $900{ }^{\circ} \mathrm{C}$ (Figure 6(d)) in CS-4, possibly due to insufficient $\mathrm{Al}$ activity at this temperature. Therefore, without the protection from $\mathrm{Al}_{2} \mathrm{O}_{3}$ layer, the oxide thickness of CS-4 is actually thicker than that of FC-2.0, Figure 6(h). Since lower W content would increase the rate of outward diffusion, and $\mathrm{Al}_{2} \mathrm{O}_{3}$ could not form initially in CS-4, the oxidation weight gain for CS-4 can be higher than that of FC-2.0. However, continuous $\mathrm{Al}_{2} \mathrm{O}_{3}$ does form on CS-4 eventually after $146 \mathrm{~h}$, so better oxidation protection for CS-4 can be expected for longer exposure time. At $1000{ }^{\circ} \mathrm{C}$, continuous $\mathrm{Al}_{2} \mathrm{O}_{3}$ can be detected on CS-4 only after $5 \mathrm{~h}$ exposure. Consequently, the continuous $\mathrm{Al}_{2} \mathrm{O}_{3}$ can be an effective diffusion barrier, the weight gain curve of CS-4 is lower than those of FC alloys from the start (Figure 5(b)). Furthermore, the thickness of oxidized layer is thinner than that of the $900{ }^{\circ} \mathrm{C}$ condition, even it is oxidized at $1000{ }^{\circ} \mathrm{C}$ after 146 h, Figure 6(h) and Figure 6(l).

At $1150{ }^{\circ} \mathrm{C}$, the oxidation kinetics of CS-4 clearly shows a tremendous difference in comparison with those of $\mathrm{FC}$ alloys. Although FC alloys can also differentiate themselves in terms of oxidation behavior with higher Si content, FC alloys all show rapid weight gain during the initial stage of oxidation, while CS4 can be protected more rapidly at around $50 \mathrm{~h}$. FC alloys exhibit oxidized thickness layers greater than $200 \mu \mathrm{m}$, by contrast, the overall oxide thickness of CS-4 is only about $11 \mu \mathrm{m}$. So, CS-4 is an $\mathrm{Al}_{2} \mathrm{O}_{3}$ former, its ability to resist oxidation at temperatures above $1000{ }^{\circ} \mathrm{C}$ is better than that of its counterpart FC-2.0. The reduction in $\mathrm{W}$ content has allowed $\mathrm{Al}_{2} \mathrm{O}_{3}$ to form continuously very rapidly at higher temperatures, either by increasing the diffusivity of alloy system or increasing the $\mathrm{Al}$ activity in the alloy system. During the oxidation process, $\mathrm{CoO}$ and spinels can form at the very beginning stage. Since $\mathrm{CoO}$ and spinels are not protective, the rate of oxidation are relatively fast at first, followed by internal oxidation of $\mathrm{Al}_{2} \mathrm{O}_{3}$ formation. The behavior of $\mathrm{Al}_{2} \mathrm{O}_{3}$ formation has determined the difference between $\mathrm{FC}$ alloys and CS-4. As long as the continuous $\mathrm{Al}_{2} \mathrm{O}_{3}$ can be formed, it can inhibit the interdiffusion and growth of oxide layers effectively, hence the spinels are much thinner in CS-4. Partial pressure of oxygen for $\mathrm{Al}_{2} \mathrm{O}_{3}$ formation is very low, so the formation of $\mathrm{Al}_{2} \mathrm{O}_{3}$ should be a result of inward diffusion of oxygen more than the outward diffusion of $\mathrm{Al}$, hence $\mathrm{Al}_{2} \mathrm{O}_{3}$ are formed at the interface between substrate and the top oxides such as $\mathrm{CoO}$ and spinels. In our previous study, increasing in the content of $\mathrm{Si}$ in the Co-Al-W-Ni systems beyond 2 at\% can promote the precipitation of $\mu$ phase [19]. The $\mu$ phase is thermodynamically stable at high temperature, and it can be deleterious to the high temperature mechanical properties, hence an upper limit of $2 \mathrm{at} \% \mathrm{Si}$ is the preferred content. $\mathrm{W}$ is the major $\gamma^{\prime}$ forming element in the alloy system, lower $\mathrm{W}$ contents can lead to lower volume fractions of $\gamma^{\prime}$ precipitates (Figure 1) and lower strength (Figure 4), although it has a positive effect on promoting the formation of continuous $\mathrm{Al}_{2} \mathrm{O}_{3}$. So there is a tradeoff between oxidation resistance and mechanical strength. Finally, the $\gamma^{\prime}$ solvus temperature of CS- 4 needs be higher, since its solvus temperature is below $1000{ }^{\circ} \mathrm{C}$ (Table III). Future alloy design should consider further increasing the $\gamma^{\prime}$ solvus of CS-4 by adding $\mathrm{Ta}$ or $\mathrm{Nb}$, while maintaining its $\mathrm{Al}$ activity for formation of protective $\mathrm{Al}_{2} \mathrm{O}_{3}$.

\section{Conclusions}

The followings conclusions can provide for future alloy design advanced Co-based superalloys. Addition of $\mathrm{Si}$ in $\mathrm{Co}-\mathrm{Al}-\mathrm{W}-\mathrm{Ni}$ alloy system can increase the $\gamma^{\prime}$ volume fraction and the $\gamma^{\prime}$ solvus temperature, which is consistent with the $\mathrm{Si}$ partitioning tendency toward $\gamma^{\prime}$ phase, promoting an increase of $\mathrm{K}$ value of $\mathrm{Al}$, and affecting the partitioning behavior of W. 2.0 at $\%$ Si can decrease lattice misfit and strengthen the alloy against plastic deformation at elevated temperatures. Si addition can improve oxidation resistance. $\mathrm{W}$ has a profound impact on the oxidation behavior; low content of $\mathrm{W}$ allows the formation of continuous $\mathrm{Al}_{2} \mathrm{O}_{3}$ at temperatures above $1000{ }^{\circ} \mathrm{C}$, while high $\mathrm{W}$ content can slow down oxidation at $900{ }^{\circ} \mathrm{C}$.

\section{Acknowledgements}

Authors would like to thank Dr. Woei-Ren Wang of ITRI for high temperature hardness tests; the financial support from Ministry of Science and Technology, Taiwan (R.O.C.), project grant number: 103-2221-E-214 -035, 103-2218-E-007 -019. Also authors would also like to thank Transcrystal Company for financial support for this research.

\section{References}

[1] D.R. Gaskell, "Introduction to the Thermodynamics of Materials", CRC Press, (2008) 37-66.

[2] C.T. Sims, N.S. Stoloff, W.C. Hagel, superalloys II, (1987).

[3] R. Cahn, P. Siemers, J. Geiger, P. Bardhan, "The orderdisorder transformation in Ni3Al and Ni3Al-Fe alloys-I. Determination of the transition temperatures and their relation to ductility”, Acta metallurgica, 35 (1987) 2737-2751.

[4] J. Sato, T. Omori, K. Oikawa, I. Ohnuma, R. Kainuma, K. Ishida, "Cobalt-base high-temperature alloys", Science, 312 (2006) 90-91.

[5] L. Klein, M.S. Killian, S. Virtanen, "The effect of nickel and silicon addition on some oxidation properties of novel Co-based high temperature alloys", Corrosion Science, 69 (2013) 43-49.

[6] L. Klein, A. Bauer, S. Neumeier, M. Göken, S. Virtanen, "High temperature oxidation of $\gamma / \gamma$ '-strengthened Co-base superalloys", Corrosion Science, 53 (2011), 2027-2034.

[7] A. Bauer, S. Neumeier, F. Pyczak, M. Göken, "Microstructure and creep strength of different $\gamma / \gamma$ '-strengthened Co-base superalloy variants", Scripta Materialia, 63 (2010) 1197-1200. 
[8] A. Bauer, S. Neumeier, F. Pyczak, R.F. Singer, M. Göken, "Creep properties of different $\gamma^{\prime}$-strengthened Co-base superalloys", Materials Science and Engineering: A, 550 (2012) 333-341.

[9] H.-Y. Yan, V. Vorontsov, D. Dye, "Alloying effects in polycrystalline $\gamma^{\prime}$ strengthened $\mathrm{Co}-\mathrm{Al}-\mathrm{W}$ base alloys", Intermetallics, 48 (2014) 44-53.

[10] C. Zenk, S. Neumeier, H. Stone, M. Göken, "Mechanical properties and lattice misfit of $\gamma / \gamma^{\prime}$ strengthened Co-base superalloys in the $\mathrm{Co}-\mathrm{W}-\mathrm{Al}-\mathrm{Ti}$ quaternary system", Intermetallics, 55 (2014) 28-39.

[11] F. Xue, H. Zhou, X. Ding, M. Wang, Q. Feng, "Improved high temperature $\gamma^{\prime}$ stability of Co-Al-W-base alloys containing Ti and Ta", Materials Letters, 112 (2013) 215-218.

[12] L. Klein, Y. Shen, M.S. Killian, S. Virtanen, "Effect of B and $\mathrm{Cr}$ on the high temperature oxidation behavior of novel $\gamma / \gamma^{\prime}-$ strengthened Co-base superalloys", Corrosion Science, 53 (2011) 2713-2720.

[13] P. Berthod, "Kinetics of High Temperature Oxidation and Chromia Volatilization for a Binary Ni-Cr Alloy", Oxidation of Metals, 64 (2005) 235-252.

[14] L. Klein, A. Zendegani, M. Palumbo, S.G. Fries, S. Virtanen, "First approach for thermodynamic modelling of the high temperature oxidation behavior of ternary $\gamma^{\prime}$-strengthened CoAl-W superalloys", Corrosion Science, 89 (2014) 1-5.

[15] A. Sato, Y.L. Chiu, R.C. Reed, "Oxidation of nickel-based single-crystal superalloys for industrial gas turbine applications", Acta Materialia, 59 (2011) 225-240.

[16] A. Sato, H. Harada, Y. Koizumi, T. Kobayashi, K. Kawagishi, H. Imai, "Oxidation resistances of silicon-containing 5th generation Ni-base single crystal superalloys", Journal of The Japan Institute of Metals, 70 (2006) 180-183.

[17] A.C. Yeh, K.C. Yang, J.W. Yeh, C.M. Kuo, "Developing an advanced Si-bearing DS Ni-base superalloy", Journal of Alloys and Compounds, 585 (2014) 614-621.

[18] A.C. Yeh, K. Kawagishi, H. Harada, T. Yokokawa, Y. Koizumi, T. Kobayashi, D. Ping, J. Fujioka, T. Suzuki, "Development of Si-bearing 4th generation Ni-base single crystal superalloys", Superalloys 2008, (TMS, 2008) 619-628.

[19] C.F. Cheng, "Effects of Si addition on the Co-based superalloys", Master thesis, National Tsing Hua University, 2014.

[20] B. Pieraggi, "Calculations of parabolic reaction rate constants", Oxidation of metals, 27 (1987) 177-185.

[21] D. Monceau, B. Pieraggi, "Determination of parabolic rate constants from a local analysis of mass-gain curves", Oxidation of metals, 50 (1998) 477-493.

[22] S. Mrowec, A. Stokłosa, "Calculations of parabolic rate constants for metal oxidation", Oxidation of Metals, 8 (1974) 379-391.

[23] R. Bedworth, N. Pilling, "The oxidation of metals at high temperatures”, J. Inst. Met., 29 (1923) 529-582.
[24] A.C. Yeh, S.C. Wang, C.F. Cheng, Y.J. Chang, S.C. Chang, "Oxidation behaviour of Si-bearing Co-based alloys", Oxidation of Metals, DOI 10.1007/s11085-016-9623-2 